\title{
PERLINDUNGAN HAK CIPTA TERHADAP KONTEN APLIKASI TIKTOK YANG DISEBARLUASKAN TANPA IZIN
}

\author{
Made Yunanta Hendrayana, I Nyoman Putu Budiartha \& Diah Gayatri Sudibya \\ Fakultas Ilmu Hukum, Universitas Warmadewa, Denpasar-Bali, Indonesia \\ madeyunanta@gmail.com, budiarthaputu59@gmail.com \& diahgayatridsudibya@gmail.com
}

\begin{abstract}
Abstrak
Tiktok merupakan aplikasi yang sedang populer, banyak video dari aplikasi tiktok yang menjadi terkenal. Namun ada orang - orang yang memanfaatkan hal tersebut dengan cara menggungah ulang video tiktok yang terkenal di sebuah akun khusus pada media sosial lain dan menerima endorse untuk akun tersebut. Oleh karena itu, dibutuhkan perlindungan hak cipta terhadap konten tiktok yang disebarluaskan tanpa izin. Penelitian ini membahas mengenai payung hukum yang dapat melindungi pemilik konten apabila nantinya kontenya disebar luaskan tanpa izin. Tujuan penelitian ini adalah untuk mengkaji bentuk pengaturan perlindungan Hak Cipta terhadap konten dalam aplikasi tiktok dan untuk menganalisis pertanggungjawaban terhadap pemilik konten tiktok yang kontennya disebarluaskan tanpa izin dari kreator atau pencipta. Penelitian ini menggunakan metode penelitian hukum normatif, dengan menggunakan pendektaan perundang-undangan dan pendekatan konseptual. Hasil penelitian menyatakan bahwa pengaturan perlindungan hak cipta terhadap konten dalam aplikasi tiktok diatur dalam UU Nomor 28 Tahun 2014 tentang Hak Cipta dan Ketentuan Layanan Aplikasi Tiktok yang melarang seseorang untuk mendistribusikan dan memperbanyak konten tiktok untuk tujuan komersil. Adapun pertanggungjawaban terhadap pemilik konten tiktok yang disebarluaskan tanpa izin yaitu sanksi bagi penyebar video tiktok sesuai Pasal 113 ayat 3 UU Hak Cipta dan aplikasi tiktok dapat menuntut ganti rugi dan penghentian pendistribusian terhadap konten tiktok sesuai Pasal 96 ayat (I) UU Hak Cipta.
\end{abstract}

Kata Kunci: Ganti rugi, Penyebar konten tiktok, sanksi hukum.

\begin{abstract}
Tiktok is a popular application, lots of videos from the tiktok application are becoming famous. There are people who take advantage by uploading the famous tiktok video on other social media and receiving endorsement for the account. The purpose of this research is to examine the form of Copyright protection arrangements for content in the tiktok application and to analyze the accountability of the owners of tiktok content whose content is distributed without permission from the creator or creator. This journal uses normative legal research methods. The results of the study state that the regulation of copyright protection for content in the tiktok application is regulated in Law umber 28 of 2014 concerning Copyright and Terms of Service for the tiktok Application which prohibits someone from distributing and reproducing tiktok content for commercial purposes. For the accountability of the owner of tiktok content that is disseminated without permission, namely sanctions for the distribution of tiktok videos according to Article 113 paragraph 3 of the Copyright Law and the tiktok application can demand compensation and stop distribution of tiktok content in accordance with Article 96 paragraph (I) of the Copyright Law.
\end{abstract}

Keywords: Tiktok content spreader,legalsanctions, compensation

\section{PENDAHULUAN}

Pada era Globalisasi ini khususnya pada abad ke 21, jaringan komunikasi dan jaringan internet adalah suatu hal yang penting pada kegiatan sehari-hari. Sehingga, hampir seluruh orang di belahan dunia manapun saat ini pasti memiliki atau menggunakan jaringan komunikasi dan jaringan internet. Tanpa perlu bersusah payah untuk dapat mengakses jaringan komunikasi dan jaringan internet, saat ini mereka dapat dengan mudah mengaksesnya melalui telepon seluler mereka, atau yang saat ini dikenal dengan sebutan Handphone (HP). Telepon seluler atau yang 
kita lebih kenal dengan Handphone (HP) merupakan suatu alat yang digunakan untuk berkomunikasi secara eletronik yang dapat mengirim pesan suara untuk berkomunikasi dan dapat dibawa kemana-mana. Jika sebelumnya ponsel hanya berguna sebagai alat komunikasi, namun kini terdapat berbagai fitur lai nnya yang bukan hanya berguna sebagai media komunikasi namun juga sebagai media hiburan, media bisnis, dan sebagainya. beberapa fitur yang terdapat pada ponsel seperti kamera, video, permainan, email, notes, dan berbagai media sosial lain yang berguna sebagai media hiburan.

Pada ponsel fitur media sosial yang memiliki kegunaan sebagai media hiburan merupakan fitur yang paling banyak digunakan oleh orang - orang. Media sosial merupakan suatu media online yang berguna untuk dapat memudahkan terjadinya suatu interaksi antara orang orang di seluruh dunia. Seperti yang diutarakan oleh Yan Dijk, media sosial adalah sebuah suatu tempat atau wadah yang memiliki fokus dalam hat penggunaan yang bertujuan untuk memfasilitasi mereka dalam hal beraktivitas maupun untuk berkolaborasi (Nasrullah, 2017).

Tiktok yang menarik sehingga dapat meningkatkan jumlah pengikut atau foffowers yang mereka miliki. Para konten kreator, sebutan bagi pembuat video di tiktok, mencurahkan segala kreatifitas yang dimiliki kedalam bentuk video. Untuk dapat membuat sebuah konten video tiktok yang menarik, mereka mengorbankan biaya yang tak sedikit, waktu yang mereka miliki, dan juga tenaga untuk dapat membuat video tiktok. Karena kreatifitas ide-ide yang dimiliki oleh para konten kreator tiktok, maka para konten kreator tiktok dapat melahirkan video-video yang menarik. video-video dalam konten tiktok dapat disebut dengan karya-karya intelektual karena video-video tersebut berasal dari kreatifitas daya pikir oleh otak manusia yang diwujudkan dalam suatu bentuk karya nyata. Karya-karya intelektual tersebut dilindungi sebagai Hak Kekayaan Intelektual (HKI). Intellectual Property (HKJ) menurut David I Brainbridge adalah suatu hak atas kekayaan yang muncul karena kecerdasan yang dimiliki manusia, hak tersebut muncul karena kemampuan kreatifitas yang dimiliki oleh manusia yang sebelumnya hanya berupa daya pikir kemudian dapat diwujudkan dalam suatu karya atau ciptaan yang berbentuk nyata yang memiliki manfaat atau nantinya dapat menunjang kehidupan. (Dharmawan, 2017)

Video-video yang menarik tersebut kemudian menjadi viral atau terkenal, bukan hanya di sosial media tiktok namun juga di sosial media lain, contohnya instagram, youtube, whatsapp, selain di sosial media, tak jarang banyak konten tiktok yang ditayang di Televisi Nasional. Adapun kenapa video-video tiktok dapat tersebar di sosial media lain, karena adanya fitur bagikan atau teruskan kepada orang lain atau sosial media lain. Orang-orang yang merasa suatu konten video tiktok menarik, akan meneruskannnya ke orang lain agar mereka juga dapat menonton video tersebut. Tidaklah masalah untuk seseorang membagikan atau meneruskan konten video kepada orang lain untuk dapat ditonton, karena tiktok sendiri juga menyediakan fitur bagikan atau teruskan kepada orang lain. Namun saat ini, banyak konten-konten tiktok yang diambil dan disebarkanluaskan di sosial media lain tanpa adanya kredit dari pemilik video tersebut. Tak jarang juga, beberapa akun mengupload ulang video-video tiktok di sosial media. Selain tiktok, dimana di sosial media lain tersebut, akun itu merupakan akun khusus untuk mengupload konten - konten video tiktok yang menarik dan akun tersebut memiliki banyak followers dan tak jarang juga menerima endorse karena jumlah followers mereka yang tinggi.

Penelitian (Pamungkas \& Djulaeka, 2019) membahas mengenai perlindungan hukum pemegang hak cipta atas lagu yang diunggah pada aplikasi tiktok. Hasil penelitian menyimpulkan bahwa hubungan hukum pengguna aplikasi Tiktok dengan pemegang hak cipta adalah perjanjian kerjasama yang tertuang dalam User Generated Content. Penelitian selanjutnya, menganalisis hubungan antara penggunaan aplikasi tiktok dengan perilaku narsisme pada siswa sekolah menengah pertama. Dari penelitian (Aprilian, 2019) menemukan bahwa adanya hubungan yang signifikansi antara penggunaan aplikasi Tiktok dengan perilaku narsisme semakin tinggi penggunaan aplikasi Tiktok maka akan semakin tinggi perilaku narsisme dan begitupun sebaliknya. Penelitian ini membahas mengenai perlindungan hak cipta terhadap konten aplikasi tiktok yang disebarluaskan tanpa izin. Tujuan penelitian ini adalah untuk mengkaji bentuk pengaturan perlindungan Hak Cipta terhadap konten dalam aplikasi tiktok dan untuk menganalisis 
pertanggungjawaban terhadap pemilik konten tiktok yang kontennya disebarluaskan tanpa izin dari kreator atau pencipta.

\section{METODE PENELITIAN}

Tipe penelitian hukum yang digunakan dalam penulisan penelitian ini adalah jenis penelitian hukum normatif, yakni norma hukum merupakan objek yang diteliti. Penelitian hukum normatif memiliki pengertian sebagai penelitian yang meneliti mengenai aturan hukum, terutama yang berkaitan dengan norma sebagai hasil dari proses pembentukannya dan implikasi norma tersebut setelah norma tersebut diterapkan dalam kehidupan bermasyarakat. (Diantha, et al 2018) Dengan menggunakan pendekatan perundang-undangan dan pendekatan konseptual.

Pendekatan perundang-undangan (statute approach) dilakukan dengan menelaah semua peraturan perundang-undangan dan regulasi yang bersangkut paut dengan isu hukum yang sedang ditangani (Marzuki, 2005) dan pendekatan konseptual biasanya digunakan untuk memahami makna dalam konsep peraturan perundang-undangan.

Pada penelitian ini, sumber bahan hukum yang akan digunakan ada dua sumber bahan hukum, yaitu yang pertama sumber bahan hukum primer dan yang kedua yaitu sumber bahan hukum sekunder. Bahan hukum primer merupakan seluruh peraturan hukum yang ada dan berlaku dimana ditegakkan atau dipaksakan pemberlakuannya oleh negara (Diantha, 2017). Kemudian, Bahan hukum sekunder, merupakan suatu bahan yang digunakan untuk melengkapi serta untuk memberikan suatu penjelasan terhadap bahan hukum primer yang digunakan, yaitu seperti penelitian atau has ii penelitian yang terkait dengan penelitian dan literatur yang terkait dari pendapat pakar hukum (Amiruddin dan Zainal Asikin, 2008) Adapun pada penulisan penelitian ini mengunakan teknik studi dokumen. Teknik studi dokumen sendiri memiliki pengertian sebagai teknik unruk mengumpulkan bahan hukum yang bersumber dari kepustakaan yang memiliki relevansi dengan permasalahan yang sedang di bahas. Setelah seluruh bahan hukum terkumpul baik itu bahan hukum primer maupun sekunder, selanjutnya bahan hukum tersebut akan diteliti dengan cara menganilis bahan tersebut menggunakan teknik analisis bahan hukum. Pada penelitian ini analisis bahan hukum dilakukan dengan mengunakan teknik atau metode, Intepretasi ekstensif dan restriktif dan Analisis deskriptif. Pada akhirnya data dapat disatukan dan di jabarkan yang kemudian menghasilkan penelitian yang tidak melenceng dari Hukum PositifDengan demikian data dapat digabungkan dengan berbagai referensi buku hukum yang terkait dan menghasilkan skripsi yang tidak melenceng dari hukum positif. (Ahmad, 2008).

\section{PEMBAHASAN}

\section{Pengaturan Perliodungan Hak Cipta Terhadap Konten Tiktok}

Di Indonesia sendiri konsep perlindungan hukumnya dimaknai dengan cara penghayatan terhadap kesadaran akan perlindungan bagi harkat dan martabat manusia yang intinya bersumber pada asas Negara Hukum Pancasila. (Atmadja dan Budiartha, 166:2018) Hak Cipta merupakan hak yang hanya khusus dapat dimiliki atau diperoleh oleh pencipta setelah ciptaan atau karya miliknya diwujudkan kedalam suatu bentuk yang nyata. Hak Cipta termasuk kedalam salah satu substansi dari Hak Kekayaan Intelektual (HKI). Hak cipta terdapat pada bagian atau subtansi Umu Pengetahuan, Seni dan juga Sastra. Pengaturan terhadap perlindungan hak cipta sendiri diatur dengan Undang - Undang Nomor 28 Tahun 2014 tentang Hak Cipta atau yang biasa disebut dengan UU Hak Cipta.

Suatu karya ataupun ciptaan dapat terlindungi dengan Hak Cipta apabila ciptaan tersebut dihasilkan berdasarkan kemampuan intelektual manusia ke dalam suatu bentuk nyata di bidang Ilmu Pengetahuan, maupun dibidang Seni, dan atau juga di bidang Sastra. Berdasarkan ketentuan yang diatur pada Pasal 40 ayat 1 huruf (m) UU Hak Cipta, maka karya sinematografi merupakan suatu ciptaan atau karya yang dapat terlindungi oleh Hak Cipta. Karya Sinematografi merupakan suatu karya atau Ciptaan yang berbentuk atau berupa suatu gambar yang dapat bergerak (moving images), seperti contohnya film yaitu dapat berupa dokumenter, cerita, berita atau reportase serta iklan dan juga film karrun. Berkaitan dengan penelitian ini, maka konten video yang terdapat dalam aplikasi tiktok dapat dikategorikan sebagai suatu karya sinematografi. Hal tersebut didasari 
oleh konten dalam aplikasi tiktok yang berupa video atau rekaman, dimana video merupakan suatu karya yang berbentuk audiovisual atau gambar bergerak. Sehingga, konten video dalam aplikasi tiktok merupakan suatu karya intelekrual berbentuk sinematografi yang dilindungi oleh Hak Cipta.

Hak Cipta menurut ketentuan yang dalam Pasal 4 UU Hak Cipta terdiri atas Hak Moral (moral rights) danjuga Hak Ekonomi (economic rights) atas hasil karya ciptaannya. Hak Moral adalah suatu hak yang terdapat dan menempel pada pencipta, dimana hak tersebut nantinya tidak dapat dihapuskan maupun dihilangkan dengan sebab apapun itu, meskipun kedepannya kepemilikan hak cipta atau hak terkait sudah dialihkan. Pengaturan mengenai hak moral dapat dilihat pada ketentuan Pasal 5 UU Hak Cipta. Selain terdapat hak moral, pada hak cipta juga terdapat hak ekonomi. Hak Ekonomi memiliki pengertian sebagai suatu hak pencipta untuk mendapatkan suatu manfaat ekonomi dari karya atau ciptaan miliknya. Hak ini dapat memberikan izin ataupun dpaat melarang seseorang untuk mengumumkan atau memperbanyak ciptaan miliknya. Berbeda dengan hak moral, hak ekonomi dapat dipindahkan atau beralih dari penciptanya kepada orang lain. Pengaturan mengenai hak ekonomi terdapat dalam Pasal 8 dan Pasal 9 UU Hak Cipta. Berdasarkan ketentuan tersebut, maka Hak Cipta yang terdapat dalam konten video tiktok adalah Hak Moral dan juga Hak Ekonomi. Setiap konten video tiktok memiliki hak moral dan hak ekonomi yang dimiliki secara eksklusif oleh pencipta konten video tiktok. Yang berarti dalam konten video tiktok, pencipta mempunyai hak untuk dihargai dan diakui sebagai pencipta dari video tiktok karyanya serta dalam video tiktok itu wajib mencantumkan nama pencipta dari video tersebut. Sehingga apabila suatu konten video tiktok diperbanyak atau disebarluaskan, konten video tiktok tersebut wajib untuk mencanrumkan nama dari pencipta konten video tersebut, hal tersebut berkaitan dengan hak moral yang dimiliki oleh pencipta konten video tiktok.

Selain berkewajiban untuk mencantumkan nama dari pemilik atau pembuat konten video tiktok. terhadap konten video tiktok dilarang untuk diperbanyak dan atau digunakaan untuk suatu kepentingan yang memiliki nilai komersial tanpa adanya suatu persetujuan yang diberikan oleh pencipta konten tiktok atau pemegang hak cipta konten video tiktok. Sehingga orang lain yang ingin mengunakan ciptaan untuk tujuan yang bersifat komersil seperti menerbitkan, mengandakan, menerjemahkan, mengadaptasi atau mengaransemen atau mengtransformasikan, mendistribusikan, mempertunjukan, mengumumkan, dan komunikasi serta penyewaan terhadap konten aplikasi tiktok. Terhadap kegiatan tersebut wajib untuk mendapatkan persetujuan dari pencipta konten tiktok ataupun pemegang hak cipta konten video tiktok. Hal itu terkait dengan Hak Ekonomi yang yang terdapat dalam konten video tiktok. Perlindungan Hak Cipta yaitu Hak Ekonomi yang terdapat dalam konten video aplikasi tiktok, sejak pertama kali konten video tiktok tersebut dilakukan pengumuman berlaku selama lima puluh (50) tahun. Ketentuan tersebut sesuai Pasal 59 ayat (1) UU Hak Cipta. Pengumuman terhadap konten video tiktok adalah penyiaran konten aplikasi tiktok melalui alat ataupun media elektronik sehingga konten video tiktok tersebut dapat terbaca, dapat terdengar maupun dapat terlihat oleh orang lain. Ketentuan tersebut terdapat pada Pasal I angka 11 UU Hak Cipta, Selain Pengaturan Hukum pada ketentuan dalam UU Hak Cipra, pengaturan yang mengatur mengenai hak cipta terhadap konten yang terdapat dalam aplikasi tiktok juga terdapat pada bagian ketentuan layanan pada aplikasi tiktok. Ketentuan layanan aplikasi tiktok dapat diakses melalui web milik aplikasi tiktok.

\section{PertanggungjawabanTerhadap Penyebarluasan Konten Tiktok Tanpa}

Konten video tiktok yang diperbanyak atau disebarluaskan untuk suatu tujuan komersil tanpa adanya pemberitauan kepada pencipta konten tiktok atau pemegang hak cipta konten tiktok, selain bertentangan dengan pasal - pasal yang diatu dalam UU Hak Cipta,juga melanggar ketentuan layanan pada aplikasi tiktok. Berdasarkan pengaturan Pasal 113 ayat (3), yang menyatakan bahwa seseorang yang melakukan pelanggaran terhadap hak ekonomi suatu ciptaan yaitu untuk menerbitkan, mengandakan ciptaan atau karya dalam bentuk apapun, untuk mendistribusikan karya tersebut dan atau untuk mengumukan suatu ciptaan yang bersifat komersil tanpa adanya perserujuan dari pencipta atau pemegang hak cipta akan dikenakan sanksi pidana berupa 
kurungan penjara maksimal (empat) 4 tahun dan atau dengan dipidana denda paling banyak satu miliar rupiah. Sehingga setiap orang yang mengandakan konten tiktok dalam segala bentuk, mendistribusikan konten tiktok dan atau unruk mengumumkan konten tiktok dengan rujuan menghasilkan uang tanpa adanya perserujuan sebelumnya dari pencipta konten tiktok atau pemegang hak cipta konten tiktok dapat dikenakan sanksi sesuai dengan ketentuan Pasal 113 ayat (3) UU Hak Cipta, yaitu pidana berupa kurungan penjara maksimal (empat) 4 tahun dan atau dipidana denda paling banyak Rp.1.000.000.000,00 (satu miliar rupiah).

Terhadap setiap pelanggaran hak cipta terkait konten tiktok yang diperbanyak dan disebar dengan tujuan komersil tanpa adanya izin dari pemilik konten tiktok dan pemegang hak cipta konten tiktok, dapat diselesaikan melalui penyelesaian sengketa alternatif, arbitrase atau pun dapat melalui pengadilan di Pengadilan Niaga. Penyelesaian sengketa hak cipta diarur pada Pasal 95 UU Hak Cipta. Apabila seorang pencipta atau pemegang hak cipta merasa mengalami kerugian hak ekonomi terkait dengan adanya pelanggaran hak ekonomi ciptaanya, mereka berhak memperoleh pertanggungjawaban berupa ganti rugi dan menghentikan pendistribusian ataupun penggandaan terhadap ciptaan yang merupakan hasil dari pelanggaran terhadap hak ekonomi yang terdapat dalam hak cipta. Namun berdasarkan ketentuan pada layanan tiktok, yang menyatakan bahwa dengan pengguna tiktok mengirimkan konten yang dibuat oleh para pengguna melalui layanan tiktok, pengguna tiktok seruju unruk memberikan lisensi kepada tiktok secara penuh terhadap konten tiktok itu. Berdasarkan ketentuan tersebut, maka hak ekonomi yang terdapatdalam konren pengguna tiktok telah dialihkan dari pencipta konten tersebut kepada aplikasi tiktok, Sehingga memungkinkan aplikasi tiktok untuk mengandakan, mendistribusikan, dan untuk mengumumkan ciptaan ataupun terhadap hak ekonomi lainnya yang terdapat konten video tiktok. Karena peralihan hak ekonomi dari pencipta konten tiktok kepada aplikasi tiktok, apabila terjadi pelanggaran hak cipta yaitu hak ekonomi dalam konten pengguna tiktok, pencipta konten pengguna tiktok tidak dapat memperoleh pertanggungjawaban ganti rugi maupun penghentian distribusi atau penggandaan terhadap konten tiktok miliknya yang dilanggar hak ciptanya. Pertanggungjawab berupa ganti rugi maupun penghentian terhadap distribusi atau pengandaan konten tiktok yang dilanggar hak ciptanya merupakan hak dari aplikasi tiktok sebagai pemilik hak ekonomi konten tiktok.

\section{KESIMPULAN DAN SARAN}

1. Kesimpulan

Berdasarkan penjelasan hasil penelitian diatas, dapat disimpulkan bahwa:

1. Pengaturan perlindungan Hak Cipta terhadap konten dalam aplikasi tiktok diatur oleh UU Hak Cipta. Berdasarkan ketentuan pada Pasal 9 konten video tiktok dilarang untuk diperbanyak dan atau digunakaan untuk kepentingan yang menghasilkan uang tanpa adanya persetujuan dari pencipta atau pemegang hak cipta konten video tiktok. Selain diatur dengan Undang - Undang Hak Cipta, pengaturan hak cipta terhadap konten tiktok juga diarur dalam Ketentuan Layanan Aplikasi Tiktok, yang melarang pengguna tiktok untuk membuat suatu dekompilasi atau karya - karya turunan dari konten tiktok; menyebarkan, memberikan suatu lisensi, memindahkan maupun untuk menjual suatu konten tiktok; dan atau juga dengan memasarkan konten tiktok dengan memberlakukan biaya, melakukan pemasangan suatu iklan atau kegiatan yang bertujuan untuk komersil.

2. Adapun pertanggungjawaban atas konten tiktok yang disebarluaskan tanpa izin dari pencipta konten tiktok yaitu berupa sanksi sesuai dengan Pasal 113 ayat 3 UU Hak Cipta, yaitu pidana penjara maksimal (empat) 4 tahun dan atau dipidana denda paling banyak Rp.1 .000.000.000,00 (satu mi liar rupiah). Serta pencipta konten tiktok yang kontennya disebarluaskan tan pa izin berhak menerima pertanggungjawaban berupa ganti rugi dan penghentian terhadap pendistribusian ataupun penggandaan atas ciptaan yang merupakan has ii dari pelanggaran hak cipta sesuai dengan Pasal 96 ayat (I) UU Hak Cipta. Namun berdasarkan Ketentuan layanan aplikasi tiktok, Hak Ekonomi yang dimiliki oleh pencipta konten tiktok sudah beralih kepada aplikasi tiktok, sehingga yang dapat menuntut 
pertanggungjawaban berupa ganti rugi dan penghentian pendistribusian ataupun pengandaan terhadap konten tiktok adalah aplikasi tiktok bukan pencipta konten tiktok.

\section{Saran}

Memalui kajian ini, peneliti ingin menyampaikan beberapa saran untuk kiranya dapat membantu pemerintah dalam menetapkan peraturan yang dapat melindungi hak cipta pembuat konten, yaitu:

1. Pemerintah Indonesia diharapkan dapat membentuk suatu aturan ataupun kebijakan yang sesuai dengan perkembangan era teknologi saat ini untuk mengatur Hak Cipta dan Pengunaan Aplikasi yang masuk ke Indonesia terkait dengan Hak Cipta dalam Aplikasi tersebut, sehingga hak cipta yang terdapat dalam konten - konten yang diciptakan oleh masyarakat indonesia dapat terlindungi dan hak moral dan hak ekonomi yang dimiliki dapat terus dipertahankan oleh pemilik hak cipta,

2. Untuk Aplikasi tiktok agar segera membuat aturan mengenai sanksi terhadap pelanggaran hak cipta dalam konten tiktok dan mengkaji kembali aruran yang mengatur mengenai hak ekonomi maupun hak moral yang dimiliki oleh para konten kreator aplikasi tiktok agar hak moral maupun ekonomi yang dimiliki oleh pencipta konten tiktok dapat terlindungi.

\section{DAFTAR PUSTAKA}

Ahmad, B. (2008). Metode Penelitian. pustaka Setia, Bandung.

Amiruddin, \& Asikin, Z. (2008). Pengantar Metode Penelitian Hukum. PT Raja Grafindo Persada, Jakarta. Aprilian, D., Elita, Y., \& Afriyati, V. (2019). Hubungan AntaraPenggunaan Aplikasi TikTok dengan Perilaku Narsisme Pada Siswa di Sekolah Menengah Pertama. Jurnal Ilmiah Bimbingan Dan Konseling, Vol. 2(3).

Atmadja, I. D. G., \& Budiartha, I. N. P. (2018). Teori-Teori Hukum. PT. Citra Intrans Selaras, Malang.

Dharmawan, N. K. S. (2017). Buku ajar hak kekayaan intelektual. Deepublish, Yogyakarta.

Diantha, I. M. P. (2017). Metodologi Penelitian Hukum Normatif Dalam Justifikasi Teori Hukum. PT Fajar Interpratama Mandiri, Jakarta.

Diantha, I. M. P., Darmawan, N. K. S. pas ti, \& Artha, I. G. (2018). Metode Penelitian Hukum dan Penulisan Disertasi. Swasta Nulus, Denpasar.

Marzuki, P. M. (2005). Penelitian Hukum. Kencana Pranada Media Group, Jakarta.

Nasrullah, R. (2017). Media Sosial Perspektif Komunikasi, Budaya Dan Sosioteknologi (Cet.3). Simbiosa Rekatama Media, Bandung.

Pamungkas, R. T., \& Djulaeka. (2019). Perlindungan Hukum Pemegang Hak Cipta Atas Lagu Yang Diunggah Pada Aplikasi Tiktok. Simposium Hukum Indonesia, Vol.1(1). 